\title{
Development of a polymerase chain reaction diagnostic assay for Ceratomyxa shasta, a myxosporean parasite of salmonid fish
}

\author{
Oswaldo Palenzuela $^{1, *}$, Grant Trobridge ${ }^{2}$, Jerri L. Bartholomew ${ }^{1}$
}

'Department of Microbiology, Nash Hall, Room 220, Oregon State University, Corvallis, Oregon 97331-3804, USA

${ }^{2}$ Markey Molecular Medicine Center, Mailstop 357720, University of Washington, Seattle, Washington 98195-7720, USA

\begin{abstract}
A diagnostic procedure based on the polymerase chain reaction (PCR) was developed for the myxosporean parasite Ceratomyxa shasta. Three sets of oligonucleotide primers were designed to specifically amplify C shasta ribosomal RNA genes and several parameters of the assay were tested and optimised. A simple protocol for the processing of fish tissue samples was also developed. In a single round, $20 \mu \mathrm{l}$ volume reaction the optimised procedure allows the detection of $50 \mathrm{fg}$ of purified $C$. shasta genomic DNA, or 0.01 spore from a seeded fish intestine sample. This protocol is considerably faster, cheaper and more reliable than any previous diagnostic procedure for a myxosporean parasite, and can be an invaluable tool for the monitoring of early and/or subclinical C shasta infections in wild and cultured salmon populations.
\end{abstract}

KEY WORDS: Myxozoa - Diagnostics - Ceratomyxa - Polymerase chain reaction - Ribosomal RNA gene rDNA

\section{INTRODUCTION}

Myxosporeans (Myxozoa: Myxosporea) constitute a major group of fish parasites. More than 1250 species infect fresh and saltwater fishes (Lom \& Dyková 1995) and their impact on wild and cultured animals can be significant. For a number of freshwater species, it has been demonstrated that myxozoans undergo 2 developmental cycles, one of them (myxosporean) in the fish and the other (actinosporean) in an aquatic oligochaete or polychaete worm (El-Matbouli et al. 1992, Bartholomew et al. 1997). Each cycle terminates in a spore stage, which is infective for the other host. However, the routes of infection, life cycle and pathogenesis are still unknown for the vast majority of species, making their control very difficult. Although a similar model of heteroxenous life cycle is assumed for most members of the phylum Myxozoa, the identification of each putative life stage on the basis of their morphological characteristics poses important difficulties. Specific and sensitive diagnostic tools for myxozoans are thus

\footnotetext{
•E-mail: bartholj@bcc.orst.edu
}

highly desirable, and those based on conserved attributes of the parasites during this complex life cycle are currently the best choice.

Infection with Ceratomyxa shasta has been recognised as a serious impediment to salmonid aquaculture in the Pacific Northwest of North America since it was first observed in 1948 (Wales \& Wolf 1955). The parasite invades the intestinal tract of the fish, causing tissue necrosis accompanied by a severe inflammatory reaction and subsequent death of the host (Bartholomew et al. 1989a). Presumptive diagnosis of ceratomyxosis relies on the detection of mature C. shasta spores, which are found only during the terminal stage of infection. The first non-morphological approach for the diagnosis of $C$. shasta and other myxosporean species was the development of immunological or lectin-based histochemical assays (Bartholomew et al. 1989b, Adams et al. 1992, Marín de Mateo et al. 1993). However, antibodies and lectins have limited diagnostic usefulness because major antigens and lectin-binding sites can change dramatically during parasite ontogeny and they can be shared by different host cell types and by other parasite species (Lumsden 1986, Jacobson \& Doyle 
1996). Moreover, although rapid assays using tissue imprints have been developed, as reported for the diagnosis of PKX (Hedrick et al. 1992), the execution of these techniques is in general time-consuming (at least 2 to $3 \mathrm{~d}$ from sampling to results) and often requires histological techniques and equipment.

Diagnostic methods based on the detection of parasite DNA may circumvent some of these problems. Initial efforts to use DNA-based probes for the diagnosis of a myxosporean (Bartholomew et al. 1995) included the generation of Ceratomyxa shasta genomic fragments by the arbitrarily primed-polymerase chain reaction (AP-PCR). These fragments were labelled and used as probes in a dot-blot assay. A pair of oligonucleotides was also designed based on the sequence of one of these fragments, allowing the detection of $C$. shasta in infected fish tissues by PCR. Although these probes did not amplify DNA from salmon or from 2 different myxosporean species tested, diagnostic PCR probes should be preferably targeted to known genomic fragments unique to the parasite species, thus insuring the specificity of the assays. Recently, the $C$. shasta small subunit ribosomal RNA gene (SSUrDNA) was sequenced (Bartholomew et al. 1997). The availability of homologous sequences of this gene from other related and unrelated organisms allows the development of specific diagnostic probes based on divergent sequence fragments. This approach has been successfully used for the detection of PKX (Saulnier \& de Kinkelin 1997) and Myxobolus cerebralis (Andree et al. 1998) by PCR. In this work we describe the design and use of a diagnostic PCR assay for C. shasta. A simple tissue preparation method was also developed, which allows a fast and cost-effective processing of large numbers of samples.

\section{MATERIALS AND METHODS}

PCR primer selection. The Ceratomyxa shasta SSUrDNA sequence (GenBank accession no. AF001579) was manually aligned with homologous sequences of the following: 3 teleosts, Oncorhynchus mykiss (R. P. Hedrick pers comm.), Fundulus heteroclitus (M91180) and Sebastolobus altivelis (M91182): a polychaete worm, Lanice conchilega (X79873); a cnidarian, Anemonia sulcata (X53498); and 3 myxosporean parasites, Myxobolus cerebralis (U96492), Myxobolus squamalis (U96495) and Henneguya doori (HDU37549) using the Genetic Data Environment software (GDE, v 2.2) included in the GCG Wiscosin package v 9.0 (Genetics Computer Group, Madison, WI, USA). Primers were designed from regions within the $C$. shasta sequence where correct alignment was unambiguous and considerable divergence from the other sequences was found. In addition to the primers designed to be specific for C. shasta, and in order to control false-negative results caused by the absence or poor quality of template in the reactions, a set of primers designated 18 SUNI were combined to amplify a conserved region of the SSUrDNA from all the species used in this study. Primers were chosen based on the considerations of Innis \& Gelfand (1990), and their sequences were analysed with Gene Runner software (v 3.02, Hastings Software Inc. 1994) for strong secondary structure and dimer formation with themselves or with their corresponding reverse PCR primer. In addition, potential oligonucleotide sequences were sent to the BLAST electronic mail server (blast@ncbi.nlm.nih.gov) as queries to discard primers that had non-target gene homologies.

DNA extraction. All the reagents and materials used were nuclease-free. Special care was used to avoid false-positives and contamination of samples during the extraction and PCRs as proposed by Yap et al. (1994). Appropriate controls were included in every experiment, and dissecting tools were either disposable or contaminating DNA was destroyed between samples by immersion in $10 \%$ bleach for 1 min (Prince \& Andrus 1992).

For the initial development of the assay, template DNA was generated from spores of Ceratomyxa shasta, 4 other myxosporeans (Henneguya salminicola, Myxobolus arcticus, M. squamalis and Kudoa sp.) and from rainbow trout tissues, by digestion with proteinase $K$ and phenol/chloroform extraction. Briefly, samples were digested in DNA extraction buffer (100 mM NaCl, $10 \mathrm{mM}$ Tris- $\mathrm{HCl}, 25 \mathrm{mM}$ EDTA, $1 \%$ $\mathrm{w} / \mathrm{v}$ SDS $\mathrm{pH} 8$ ) with $200 \mu \mathrm{g} \mathrm{ml^{-1 }}$ proteinase $\mathrm{K}$, overnight at $37^{\circ} \mathrm{C}$ on a rocking platform. Samples were further digested with $100 \mu \mathrm{g} \mathrm{ml}^{-1}$ RNase A for $30 \mathrm{~min}$ at $37^{\circ} \mathrm{C}$, and the DNA was purified by standard phenol chloroform extraction and ethanol precipitation (Sambrook et al. 1989). Eventually, to ensure the release of DNA from resistant spores, 4 freeze-thaw cycles were added to this protocol after the initial digestion, followed by a second proteinase $\mathrm{K}$ treatment $(2 \mathrm{~h}$ at $\left.37^{\circ} \mathrm{C}\right)$

To optimise the procedure, 4 different DNA extraction methods were tested using intestinal tissues with varying intensities of Ceratomyxa shasta infection, as diagnosed by light microscopy (LM), in fresh smears of the tissue. Two small pieces of intestinal tissue 25 to $100 \mathrm{mg}$ each) were removed from each fish and placed in $1.5 \mathrm{ml}$ microtubes. The content of 1 microtube was homogenised in $10 \mu \mathrm{l}$ of TE buffer $(10 \mathrm{mM}$ Tris, $1 \mathrm{mM}$ EDTA pH 8.0) per $\mathrm{mg}$ of tissue, using a disposable plastic pestle. An aliquot of this homogenate was used as a 'crude sample' (C) for the PCR and the remainder was boiled for $5 \mathrm{~min}$, after which it was designated as 
'boiled-crude sample' (BC). Tissue in the second microtube was digested with DNA extraction buffer

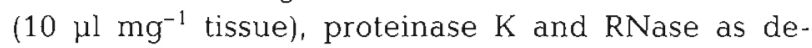
scribed above. An aliquot of this digested tissue was boiled for 5 min to inactivate the proteinase $\mathrm{K}$ and used as 'boiled-digested sample' (BD). Finally, the DNA of the remaining digested tissue was purified by phenol/ chloroform extraction and ethanol precipitation, after which it was resuspended in $50 \mu \mathrm{L}$ TE and labelled as 'extracted-digested sample' (ED).

To determine the potential sensitivity of the optimised extraction method and PCR assay for infected fish, a Ceratomyxa shasta infection was simulated by adding dilutions of Percoll ${ }^{\circledR}$ (Pharmacia Biotech, Uppsala, Sweden) purified spores (Bartholomew et al. 1989 b) to uninfected rainbow trout tissue. Fish gut pieces (50 to $90 \mathrm{mg}$ each) in $500 \mu \mathrm{l}$ of DNA extraction buffer were seeded with C. shasta spores, for final 10 fold decreasing concentrations of $10^{6}$ to 0 spores per ml of sample. Two replicate pieces of tissue were seeded with each dose of spores, and then digested and processed as for the BD samples (see above).

The DNA content of all the samples was determined with a fluorometer (Hoefer, San Francisco, CA, USA). Samples were stored at $-20^{\circ} \mathrm{C}$ until used, and diluted with HPLC-grade $\mathrm{H}_{2} \mathrm{O}$ (Sigma, St Louis, MO, USA) as needed.

Polymerase chain reaction. All reactions were performed in $20 \mu \mathrm{l}$ final volumes, with Promega (Madison, WI, USA) Taq polymerase reaction buffer $(50 \mathrm{mM} \mathrm{KCl}$, $10 \mathrm{mM}$ Tris- $\mathrm{HCl} \mathrm{pH} 9.0$ and $0.1 \% \mathrm{v} / \mathrm{v}$ triton $\mathrm{X}-100$ ) containing $0.2 \mathrm{mM}$ of each dNTP, $2 \mathrm{mM} \mathrm{MgCl}_{2}, 0.5 \mu \mathrm{M}$ of each primer and $1 \mathrm{U}$ of Taq DNA polymerase (Promega). One microlitre of template DNA at variable concentrations in $\mathrm{H}_{2} \mathrm{O}$ was used in each reaction. The components were overlaid with mineral oil, and the amplification reactions were carried out in an
Amplitron II thermal cycler (Barnstead-Thermolyne, IA, USA). The mixtures were denatured for $3 \mathrm{~min}$ at $95^{\circ} \mathrm{C}$ and amplification was performed with 35 cycles consisting of: $1 \mathrm{~min}$ for denaturation at $94^{\circ} \mathrm{C}$, then $30 \mathrm{~s}$ for primers annealing at $55,58,60$ or $65^{\circ} \mathrm{C}$ and finally $1 \mathrm{~min}$ for Taq extension at $72^{\circ} \mathrm{C}$. Ten microlitres of each reaction product were electrophoresed in 1 to $1.5 \%(\mathrm{w} / \mathrm{v}) 1 \times$ TAE $(40 \mathrm{mM}$ Tris acetate, $1 \mathrm{mM}$ EDTA $\mathrm{pH}$ 8.3) agarose gels containing ethidium bromide and visualised under UV transillumination.

\section{RESULTS}

Three sets of primers (Table 1) were designed to specifically amplify Ceratomyxa shasta SSUrDNA. Most possible combinations of these primers were tested for specificity, product size and unique conspicuous bands in the PCR products. All the primer sets resulted in specific detection of C. shasta DNA, yielding amplicons of the predicted size (Figs. $1 \& 2$ ). The identity of the products amplified with primers Cs1 \& Cs3, Cs1 \& Cs4 and Cs2 \& Cs4 was confirmed as $C$. shasta SSUrRNA gene fragments by direct sequencing (data not shown). Reactions using 'universal' 18SUNI

Table 1. Oligonucleotide primers designed

\begin{tabular}{|ll|}
\hline Primer name & $5^{\prime}-3^{\prime}$ Sequence \\
\hline Cs1 & gggccttaaadccagtag \\
Cs2 & attacaagggtcaatacttgc \\
$\mathrm{R}$ & ttgtatagcgtgccttgaat \\
Cs3 & ccgttcaggttagttacttg \\
Cs4 & tctcagtagaacgacaaatgc \\
Cs5 & ggagagaccaacttggctc \\
18SUNI(f) & ttaattgactcaacacggg \\
18SUNI(r) & gggcatcacagacctgtta \\
\hline
\end{tabular}

\section{C. shasta SSUrDNA}

Fig. 1. Ceratomyxa shasta small subunit ribosomal RNA gene primer map. Predicted amplicon sizes obtained with different combinations of the oligonucleotides are given in base pairs

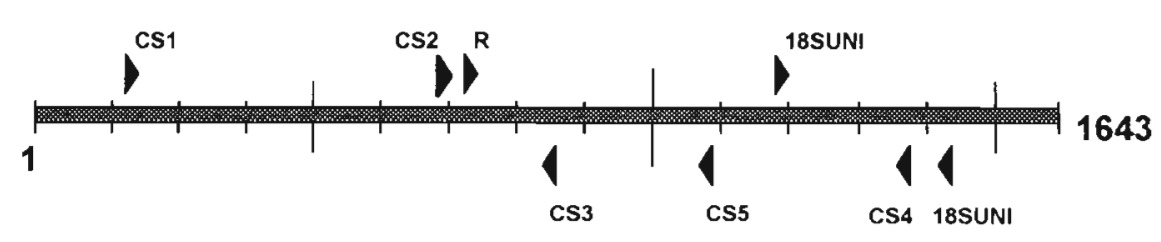

404: CS2-CS5

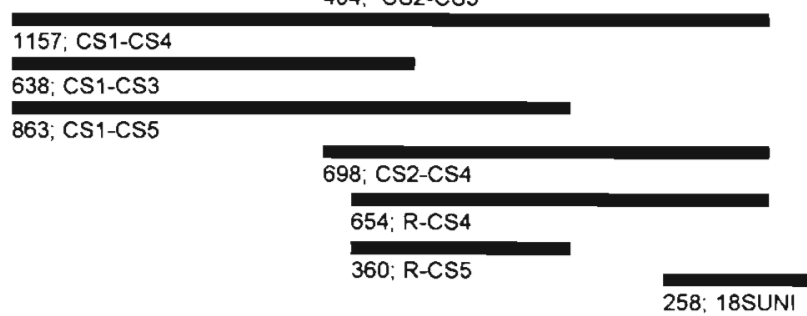




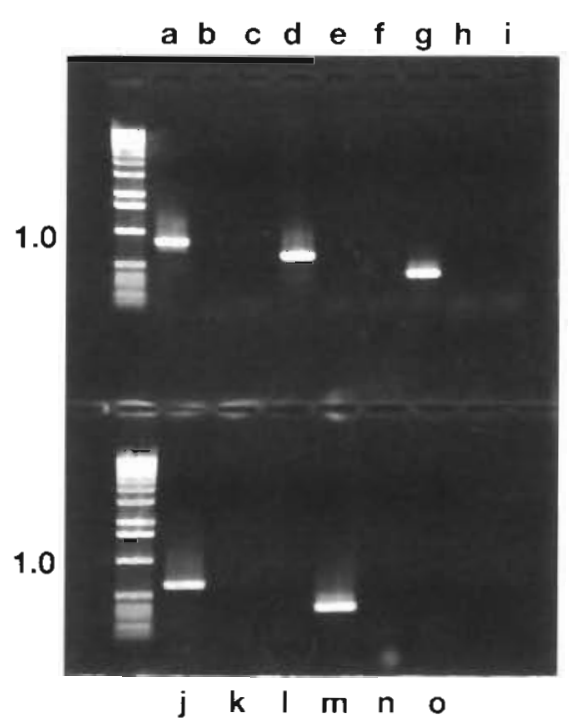

Fig. 2. Specificity of some combinations of the Ceratomyxa shasta primers with purified DNA from: $C$. shasta spores (lanes $a, d, g, j, m$ ), rainbow trout (lanes b, e, h, k, n) and Henneguya salminicola (lanes $c, f, i, l, 0)$. Primer sets used are Cs1 \& Cs5 (lanes a-c); Cs1 \& Cs3 (lanes $\mathrm{d}-\mathrm{f}$ ); Cs2 \& Cs5 (lanes g-i); R \& Cs4 (lanes j-1) and R \& Cs5 (lanes m-0). PCRs were carried out as described in the text, with temperature = $55^{\circ} \mathrm{C}$ and template DNA at $50 \mathrm{pg}$ per reaction. One percent agarose gel, ethidium-bromide stained

oligonucleotides (Table 1) yielded variable size amplicons with all the different templates used in this study (258 to 442 base pairs, bp), consistent with the size of the rDNA of each organism in the target region. The 18 SUNI primers were subsequently used as controls for the presence of template DNA in the reactions, thus demonstrating suitability for PCR amplification. Primers Cs1 \& Cs3 were chosen for further tests on sensitivity, specificity and optimisation of the assay.

\section{Specificity}

The specificity of primer set Cs1 \& Cs3 was evaluated with genomic DNA from 4 different myxosporean species and from rainbow trout (Fig. 3). These oligonucleotides specifically primed Ceratomyxa shasta rRNA genes, but none of the other templates tested. When primers 18SUNI(f) \& 18SUNI(r) were used in the reactions, it was clear that all the myxosporean and rainbow trout samples tested contained amplifiable SSUrDNA (Fig. 3). Primer sets Cs1 \& Cs3 and Cs1 \& Cs4 were also used in PCRs with samples of C. shastainfected tissues from different sites throughout the geographic range of this parasite. Infected samples from Idaho, California, Oregon (USA) and British Columbia (Canada) were positive by $\mathrm{PCR}$, yielding amplicons of the expected size (data not shown).

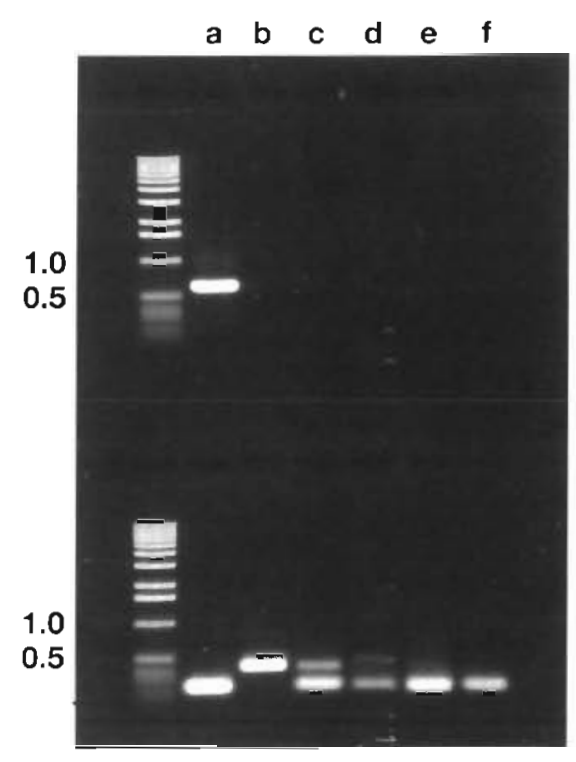

Fig. 3. Specificity of primers Cs1 \& Cs3 (top) and 18SUNI(f) \& 18SUNI(r) (bottom) with purified DNA from: Ceratomyxa shasta (lane a), Myxobolus squamalis (b), Myxobolus arcticus (c). Henneguya salminicola (d), Kudoa sp. (e) and rainbow trout (f). PCRs were carried out with template DNA at $500 \mathrm{pg}$ $(\mathrm{a}, \mathrm{b}, \mathrm{c}, \mathrm{f}), 10 \mathrm{ng}(\mathrm{d})$ and $30 \mathrm{ng}$ (e) per reaction, and temperature $=58^{\circ} \mathrm{C}$. One percent agarose gel, ethidium-bromide stained

\section{DNA extraction method}

'Crude' and 'boiled-crude' fish tissue-preparation methods produced inconsistent amplifications including false-negatives and contradictory results at different dilutions of the samples (not shown). In contrast, template DNA generated by digestion of the tissues followed by either phenol/chloroform extraction or a 5 min boiling was equally suitable for PCR as determined by the presence of consistently amplified Ceratomyxa shasta DNA fragments on ethidium bromidestained agarose gels. Comparison of the sensitivity of the PCR assay using template DNA generated by both techniques is illustrated in Fig. 4. It must be noted that $\mathrm{BD}$-generated samples had to be diluted at least 1:50 in water to produce repeatable PCR results, while the fully extracted samples were suitable undiluted.

\section{Sensilivity}

The sensitivity of the PCR with primers Cs1 \& Cs3 was evaluated using phenol/chloroform-extracted Ceratomyxa shasta DNA from Percoll purified spores. Under the optimum conditions for the assay $158^{\circ} \mathrm{C}$ annealing temperature and reaction components as described in 'Materials and methods'), as low as $50 \mathrm{fg}$ 


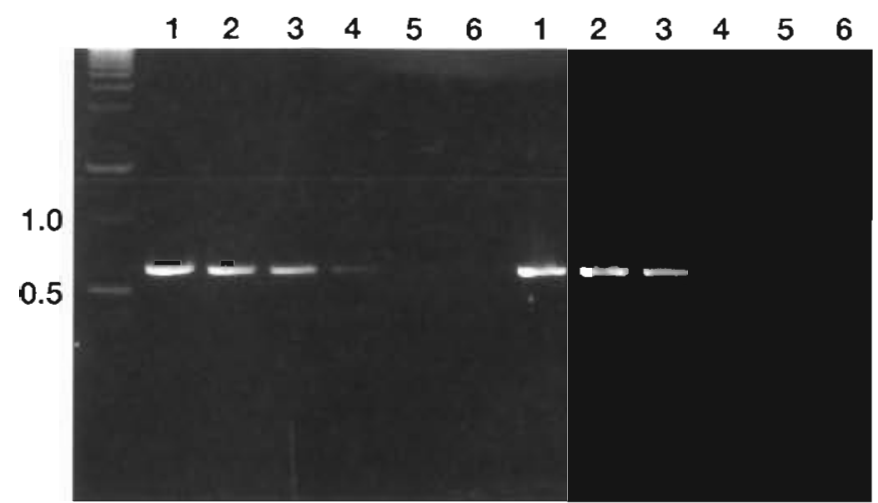

Fig. 4. Comparison of 'boiled-digested' and 'extracteddigested' sample preparation methods. Genomic DNA from Percoll ${ }^{*}$ purified Ceratomyxa shasta spores was obtained by proteinase $\mathrm{K}$ digestion, followed by phenol/chloroform extraction (left) or $5 \mathrm{~min}$ incubation at $100^{\circ} \mathrm{C}$ (right). PCRs were carried out with primers Cs1 \& Cs3 and temperature = $58^{\circ} \mathrm{C}$. Template DNA was used in 10 -fold decreasing concentrations, from $50 \mathrm{pg}$ (lane 1) to $0.5 \mathrm{fg}$ (lane 6) per reaction. One percent agarose gel, ethidium-bromide stained

of DNA were detected (Fig. 4). When template DNA was obtained from naturally infected fish intestines with different intensities of infection by $C$. shasta, all infected samples, regardless of their intensities (evaluated by light microscopy), were positive by PCR. Furthermore, several samples diagnosed as uninfected by the visual examination were found positive by PCR. No visually positive samples were found uninfected by PCR.

In uninfected tissue samples seeded with purified Ceratomyxa shasta spores, the limit of sensitivity was achieved with those samples containing $10^{3}$ spores $\mathrm{ml}^{-1}$ (Fig. 5). Given that these samples were diluted $1: 100$ and $1 \mu \mathrm{l}$ of sample was used for each amplification reaction, the assay detection limit was 0.01 spores per $20 \mu l$ PCR mixture.

\section{DISCUSSION}

An increasing number of PCR-based protocols have been developed for the detection and identification of fish and shellfish pathogens (Leong 1995, Kent et al. 1996). These assays are particularly useful for the diagnosis of fastidious organisms which cannot be grown in culture or for those whose morphology does not permit confident visual identification (Weiss 1995, McManus \& Bowles 1996), as is the case for myxosporeans. When compared to morphological, immunological or chemical methods, PCR is in general much more specific, sensitive and reliable. However, many pathology laboratories are still reticent in the use of these new technologies (Leong 1995). Most published PCR protocols

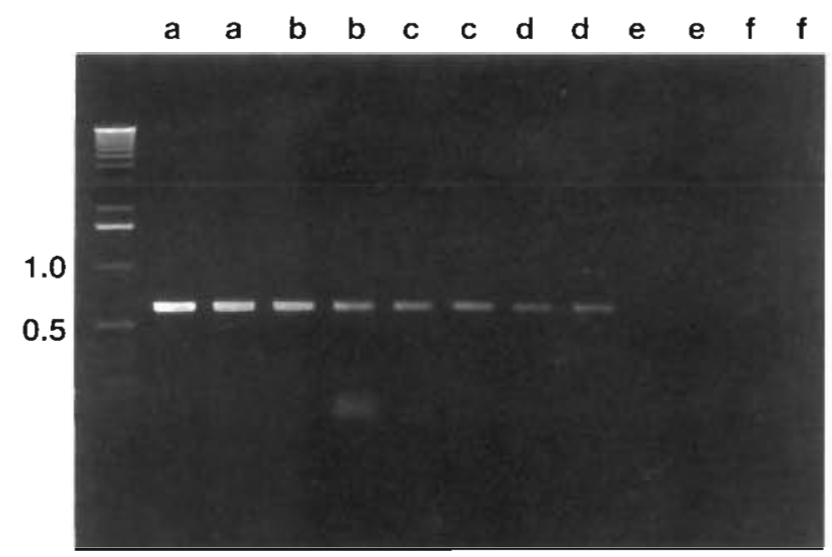

Fig. 5. Sensitivity of Ceratomyxa shasta primers Cs1 \& Cs3, with DNA from uninfected gut tissue seeded with known numbers of spores and processed by the simplified, boilingdigesting preparation method. Two replicate samples containing 10 -fold decreasing concentrations of $10^{6}$ to 0 spores $\mathrm{ml}^{-1}$ were processed, diluted 1:100 in water and used as templates for the reactions. The corresponding number of $C$. shasta spores used per reaction ranges from 10 spores (lanes a) to 0.001 spores (lanes e). Lanes f do not contain C. shasta spores (negative controls). PCRs were carried out with temperature $=58^{\circ} \mathrm{C}$. One percent agarose gel, ethidiumbromide stained

involve time-consuming and expensive steps, like protein extraction with organic solvents, and ambiguous results can be obtained when these assays are performed by non-experienced personnel. Our purpose was to produce a sensitive and simple assay for the diagnosis of Ceratomyxa shasta, based on the SSUrDNA of this parasite. In addition to the increased sensitivity achieved with oligonucleotide primers targeted to a multiple copy gene, the availability of a large and continuously growing number of related and unrelated sequences allows the design of highly specific probes. Furthermore, the SSUrDNA displays significant inter- and intrageneric variability in the Myxozoa (Andree et al. 1999, authors' unpubl. data); thus, it is relatively simple to design probes for the discrimination of closely related myxosporean species.

Probably the main constraint of PCR diagnostic methods is the time-consuming, relatively expensive and hazardous traditional DNA extraction methods Alternative protocols, based on commercial DNA binding resins and spin-columns are an easy and safe alternative, but their cost and the need for centrifugation are limiting factors. For the Ceratomyxa shasta PCR, we found the extraction and precipitation steps which typically follow digestion of tissues (Sambrook et al. 1989) to be unnecessary. Comparable results were obtained with 5 min incubation in boiling water, allowing the procedure to be completed in one tube and without centrifugation. This simple procedure not 
only reduces dramatically the chances of cross-contamination between samples and the time and expense of the procedure, but it also allows simultaneous processing of a large number of samples.

Using primers Cs1\&Cs3 and the simplified tissue preparation procedure, as low as $50 \mathrm{fg}$ of phenol/chloroform-extracted DNA was detected from purified Ceratomyxa shasta spores, or 1/100th of a spore from C. shasta-seeded, uninfected fish tissue. A similar sensitivity limit has previously been reported in a diagnostic assay for the microsporidian Loma salmonae (Docker et al. 1997). Although a gross estimation, these data suggest the existence of a minimum of 100 IDNA gene copies per $C$. shasta spore. To produce consistent results boiled samples had to be diluted at least 1:50, and a 1:100 dilution is routinely used in our laboratory. Thus, the overall sensitivity achieved with these samples is lower than the potential detection limit obtained with fully extracted samples. However, this level is sufficient for most purposes and the simplification of the procedure is worth the loss in sensitivity. The inconsistency of the PCR with more concentrated BD samples is probably caused by the presence of Taq inhibitors (Rossen et al. 1992), or by residual activity of proteinase $\mathrm{K}$.

Only 2 PCR-based assays for the detection of myxozoans have been reported to date. The procedure for Myxobolus cerebralis can detect 1 parasitic cell in a single, $50 \mu$ volume reaction, though results may become equivocal at a very low parasite to host DNA ratio (Andree et al. 1998). These authors also developed a nested approach, more sensitive and robust under all levels of infection examined. The sensitivity reported for the PKX-specific PCR is lower, about 5 cells per $100 \mu \mathrm{l}$ reaction (Saulnier \& de Kinkelin 1997). However, the latter presents the advantage of an extremely simple tissue-processing method, a single boiling step without any enzymatic digestion. Nevertheless, in our hands this procedure was inconsistent for the detection of Ceratomyxa shasta at low infection levels.

By PCR, Ceratomyxa shasta infections in gut tissue were diagnosed from experimentally infected trout, as soon as $5 \mathrm{~d}$ following exposure (data not shown). Although the procedure has been extensively tested on intestinal tissue, it can be easily adapted for different biological samples. Parasite DNA was detected from whole gill arches and from pieces of skin and muscle, as early as $2 \mathrm{~d}$ after exposure to $C$. shasta actinospore stages. $C$. shasta stages have also been detected by PCR in water samples and from tissues of the polychaete host, Manayunkia speciosa (Bartholomew et al. 1997). The PCR for C. shasta has been demonstrated a powerful tool for detecting all the stages of this parasite in the fish and in a variety of bio- logical samples. The increased sensitivity afforded by the PCR is invaluable for monitoring early or subclinical infections, allowing the development of prophylactic policies for the introduction of fish to parasite-free areas. The development of similar assays for other myxozoans can contribute to a better understanding of their biology and epidemiology, and could contribute to strategies for reducing the impact of these parasites on wild and cultured fish populations.

Acknowledgements. The authors thank Jason Waithman for his assistance in the fish sampling and PCRs, Ken Peters (Bozeman Fish Health Center, MT, USA) for providing blind samples and testing the assay in his lab, and the staff at the Salmon Disease Laboratory (Oregon State University); Harriet Lortz, Don Stevens and Margaret Whipple for their assistance. We also thank Dr Michael Kent and Dr Ronald Hedrick for providing $C$. shasta-infected samples from Canada and California. O.P. was recipient of a fellowship from the 'Departamento de Educacion, Universidades e Investigacion del Gobierno Vasco'. This work was partially supported by grant no. NA36RG0451 (project no. R/FSD-26) from the National Oceanic and Atmospheric Administration of the Oregon State University Sea Grant College Program and by appropriations made by the Oregon State Legislature. The views expressed herein are those of the authors and do not necessary reflect the views of NOAA or any of its subagencies. The U.S. Department of Agriculture provided additional support for this project under the Animal Health and Disease CRIS project no. ORE00038 and the National Research Initiative Competitive Grants Program, award no. 95-37204-2350. This is Oregon Agricultural Station Technical paper no. 11346.

\section{LITERATURE CITED}

Andree KB, MacConnell E, Hedrick RP (1998) A nested polymerase chain reaction for the detection of genomic DNA of Myxobolus cerebralis in rainbow trout (Oncorhynchus mykiss). Dis Aquat Org 34:145-154

Andree KB, Székely C, Molnár K, Gresoviac SJ, Hedrick RP (1999) Relationships among members of the genus Myxobolus (Myxozoa: Bivalvulida) based on small subunit ribosomal RNA sequences. J Parasitol 85(1):68-74

Adams A, Richards RH, Marín de Mateo M (1992) Development of monoclonal antibodies to $\mathrm{PKX}$, the causative agent of proliferative kidney disease. J Fish Dis 15: 515-521

Bartholomew JL, Smith CE, Rohovec JS, Fryer JL (1989a) Characterization of a host response to the myxosporean parasite, Ceratomyxa shasta (Noble), by histology, scanning electron microscopy and immunological techniques. $\mathrm{J}$ Fish Dis 12:509-522

Bartholomew JL, Rohovec JS, Fryer JL (1989b) Development, characterization, and use of monoclonal and polyclonal antibodies against the myxosporean, Ceratomyxa shasta. J Protozool 36(4):397-401

Bartholomew JL, Rodriguez RJ, Arakawa CK (1995) Development of a DNA probe for the myxosporean parasite Ceratomyxa shasta, using the polymerase chain reaction with arbitrary primers. Dis Aquat Org 21:215-220

Bartholomew JL, Whipple MJ, Stevens DG, Fryer JL (1997) The life cycle of Ceratomyxa shasta, a myxosporean parasite of salmonids, requires a freshwater polychaete as an 
alternate host. J Parasitol 83(5):859-868

Docker MF, Devlin RH, Richard J, Khattra J, Kent ML (1997) Sensitive and specific polymerase chain reaction for detection of Loma salmonae (Microsporea). Dis Aquat Org 29:41-48

El-Matbouli M, Fischer-Scherl T, Hoffmann RW (1992) Present knowledge on the life cycle, taxonomy, pathology, and therapy of some Myxosporea spp. important for freshwater fish. In: Faisal M, Hetrick FM (eds) Annual review of fish diseases. Pergamon Press, New York, p 367-402

Hedrick RP, Marín de Mateo M, Castagnaro M, Monge D, de Kinkelin P (1992) Rapid lectin-based staining procedure for the detection of the myxosporean causing proliferative kidney disease in salmonid fish. Dis Aquat Org 13: $129-132$

Innis MA, Gelfand DH (1990) Optimization of PCRs. In: Innis MA, Gelfand DH, Sninsky JJ, White TJ (eds) PCR protocols: a guide to methods and applications. Academic Press, San Diego, p 3-12

Jacobson RL, Doyle RJ (1996) Lectin-parasite interactions. Parasitol Today 12(2):55-61

Kent ML, Hervio DML, Docker MP, Devlin RH (1996) Taxonomy studies and diagnostic tests for myxosporean and microsporidian pathogens of salmonid fishes utilising ribosomal DNA sequence. J Eukaryot Microbiol 43(5): 98S-99S

Leong JC (1995) Molecular biological tools to detect fish pathogens. J Fish Biol 47:61-75

Lom J, Dyková I (1995) Myxosporea (Phylum Myxozoa). In: Woo PTK (ed) Fish diseases and disorders, Vol 1. Protozoan and metazoan infections. University Press, Cambridge, p $97-148$

Lumsden WHR (1986) Application of immunological methods in protozoology. In: Weir DW (ed) Handbook of experimental immnunology, Vol 4. Applications of immunological methods in biomedical sciences, 4 th edn. Blackwell Scientific Publications, Oxford, p 1-19

Marín de Mateo M. Adams A, Richards RH, Castagnaro M, Hedrick RP (1993) Monoclonal antibody and lectin probes recognize developmental and sporogonic stages of PKX, the causative agent of proliferative kidney disease in European and North American salmonid fish. Dis Aquat Org 15:23-29

McManus DP, Bowles J (1996) Molecular genetic approaches to parasite identification: their value in diagnostic parasitology and systematics. Int J Parasitol 26(7):687-704

Prince AM, Andrus L (1992) PCR: how to kill unwanted DNA BioTechniques 12(3):358-360

Rossen L, Norskov P, Holmstrom K, Rasmussen OF (1992) Inhibition of PCR by components of food samples, microbial diagnostic assays and DNA-extraction solutions. Int $\mathrm{J}$ Food Microbiol 17:37-45

Sambrook J, Fritsch EF, Maniatis T (1989) Molecular cloning. A laboratory manual, 2nd edn. Cold Spring Harbor Laboratory Press, New York

Saulnier D, de Kinkelin P (1997) Polymerase chain reaction primers for investigations on the causative agent of proliferative kidney disease of salmonids. J Fish Dis 20:467-470

Wales $\mathrm{JH}$, Wolf $\mathrm{H}$ (1955) Three protozoan parasites of trout in California. Calif Fish Game 41:183-187

Weiss JB (1995) DNA probes and PCR for diagnosis of parasitic infections. Clin Microbiol Rev 8:113-130

Yap EPH, Lo YMO, Fleming KA, McGee JO'D (1994) Falsepositives and contamination in PCR. In: Griffin HG, Griffin AM (eds) PCR technology: current innovations. CRC Press, Boca Raton, p 249-258

Submitted: May 19, 1998; Accepted: September 30, 1998 Proofs received from author(s): March 25, 1999
Editorial responsibility: Wolfgang Körting

Hannover, Germany 